\title{
A hermeneutical-homiletic reading of Psalm 37 with reference to H J C Pieterse's homiletics
}

\author{
C J A Vos \\ University of Pretoria
}

ABSTRACT

A hermeneutical-homiletic reading of Psalm 37 with reference to $\mathbf{H} \mathbf{J}$ C Pieterse's homiletics

In this article Psalm 37 is viewed hermeneutic-homiletically. The sociohistorical context of Psalm 37 is considered. Furthermore, the structure of the Psalm receives attention, as does its posture. Particular emphasis is placed on the term "righteous" as it functions in the Psalm. More specifically, manifestation of the Psalm is traced in the homiletics of $\mathrm{H} \mathrm{J}$ $C$ Pieterse. The "just man" serves as the sermon's homiletic context within his homiletics, and preaching the gospel to the victims of social injustice stands central to it. This article expresses an appreciation for the valued contribution, particularly in homiletics, that has been made by Pieterse.

\section{ORIENTATION}

The approach followed in this article begins with a hermeneuticalhomiletic examination of Psalm 37 in a search for the message to the distressed. The next step is to examine the way in which the preaching of the celebrated homilete, Hendrik J C Pieterse, echoes Psalm 37.

\section{A SEARCH FOR RIGHTEOUSNESS ACCORDING TO PSALM 37}

\subsection{The socio-historical context of Psalm 37}

One of the biggest religious crises in post-exilic Israel was the experience of living in turmoil. Disillusionment and disappointment perturbed the traditional way of life and inescapably led people to question God's justice and even his presence (Irsigler 1997:71). The question became crystallised into a "charge against God", which is characteristic of the laments in Israel and in the Ancient East (cf Sitzler 1995). Psalm 37 is an attempt to make sense of the nonsense of disillusionment and turmoil (Mays 1993:159). Insight is provided by a perspective of God and his dealings with men on the way to the future (Van Uchelen 1971:245-246; Zenger 1993:229). Irsigler (1997:77) is of the opinion that Psalm 37 owed its origin to and primarily impacted upon a local community of adherents of Yahweh, inside or outside Jerusalem. 
Like the Book of Job, Psalm 37 postulates an individual and efficacious retribution. This perspective was developed with pastoral insight by Ezekiel during the exile (Irsigler 1997:72). The use of the plural the wicked in a polemic sense occurred for the first time in Jeremiah 5:26. The typical contrasting of the "wicked" and the "righteous" is characteristic of post-exilic literature in Israel, for example in Malachi, in the Psalms, Job and in Proverbs (Irsigler 1997:72). The motif of the happiness of the wicked, giving rise to envy and jealousy among the followers of Yahweh, is especially frequent in the post-exilic texts of the $5^{\text {th }}$ century. Some examples are: Malachi 2:17; Job 21:7-21; Proverbs 3:31; 23:17; 24:1 and 19 (Irsigler 1997:73). As a broad background to Psalm 37, the Persian period of the $5^{\text {th }}$ and $4^{\text {th }}$ centuries B.C. should not be lost sight of (Zenger 1993:229-230; Irsigler 1997:73; footnote 11, 78-79).

\subsection{Structure}

Psalm 37 is a classical example of a wisdom psalm (Van der Ploeg 1973:236; Weiser 1987:212; Brueggemann 1993:230; Zenger 1993:229; Lohfink 1997:234). Like all wisdom psalms, Psalm 37 has a didactic character. The poet takes on the characteristics of a teacher. He speaks from experience and shares his wisdom with the ignorant. The psalm also has an alphabetical structure in which the initial letters of alternative verses are structured according to the Hebrew alphabet (Van Uchelen 1971:245: Van der Ploeg 1973:237; Zenger 1993:230; Irsigler 1997:74; Lohfink 1997:234).

Although Psalm 37 is built up of a succession of proverbs, it is nevertheless possible to distinguish, in terms of both form and function, three locutionary acts, made up as follows (Zenger 1993:230-231; Irsigler 1997:74):

Verses 1-11

Verses 1-4

Verses 5-8

Verses 9-11

Verses 12-26

Verses 12-24 general exposition

Verses 25-26 autobiographical

confession of faith
Appellative proverbs:

Warning against "envy"

Invitation to trust in Yahweh

summing up of motivation

Instructional proverbs:

Instruction on the ways of the "wicked and the righteous" 
Verses 27-40

Verses 27-34 appeal and general

Verses 35-36 autobiographical

confession of faith

Verses 37-40 concluding exhortation

and motivation:
Appellative and instructional proverbs

Summary and inculcation exposition

“Future” (vv 37,38)

\subsection{Texture}

The first strophe (vv 1-11) is characterised by appeals with motivations (ki, vv 2-9) and announcements (Irsigler 1997:75). The second strophe is mainly descriptive. In the third strophe (vv 27-40) the preceding strophes are summarised by means of imperative clauses and statements. A confession in the first person follows in verses 35-36. The concluding exhortation directs us towards the future (Zenger 1993:229-231; Irsigler 1997:75).

The psalm is not explicitly a prayer. Yahweh is not addressed directly. The only internal communication in the text proceeds from the speaker, who refers in the autobiographical passages to his age and his experience as a šaddiq (Zenger 1993:236-237; Irsigler 1997:75).

A number of poetical strategies are evident in Psalm 37. Only a few will be discussed here. The poet uses antithetical parallelism, an example of which is to be found in verse 9 .

"For evil men will be cut off but those who hope in the Lord...".

In order to describe the destruction of the wicked, the poet uses a military metaphor which expresses irony: Although the wicked draw the sword in order to slay the righteous, their plans will come to nought and “...their swords will pierce their own hearts and their bows will be broken" (vv 15).

A simile is used to illustrate the fact that the success of the wicked is short-lived, and to persuade the righteous not to worry about the wicked, "for like the grass they will soon wither, like green plants they will soon die away" (v 2).

Psalm 37 concentrates on everyday life. Although the emphasis is on the salvation which the Lord brings ( $\mathrm{cf} \mathrm{vv} 39$ and 40 in particular), man's responsibility also comes in for scrutiny. 


\subsection{Posture}

Psalm 37 is a wisdom psalm in which a skilfully composed poem (in structure and texture) is used to persuade the reader to trust in the Lord. The first part of the psalm ( $\mathrm{vv} 1-11$ ) aims to comfort (reassure) the readers and refresh their faith in Yahweh (Van Uchelen 1971:246-247; Weiser 1987:213-214; Zenger 1993:234-235; Irsigler 1997:75). It is this faith that the reader must draw on for strength to live courageously, even in the midst of misfortune.

The second strophe part ( $\mathrm{vv} 12-26$ ) contains instruction on the ways of the wicked and of the righteous. This strophe is concluded with an autobiographical statement of faith by the speaker in the first person (vv 25-26) (Zenger 1993:235-237; Irsigler 1997:75). The most important function of the psalm is to persuade the righteous to trust in God and obey him despite the actions of the wicked. The prosperity enjoyed by the wicked could tempt the righteous to envy them and fall into unbelief. The psalm tells us, however, that the prosperity of the wicked is temporary and that the reward of the righteous is permanent and sure. The claim that the righteous shall inherit the earth is repeatedly used to express this idea (cf vv 3, 9, 11, 18, 22, 27, 34). All things will work together for good for the righteous.

However, when confronted by the realities of life we cannot deny that the message of Psalm 37 offers only a partial solution to the problems and conflicts of our world. Life treats many people harshly, and the righteous are not spared. For this reason Psalm 37 cannot be studied in isolation from the rest of the Old Testament. Job and the individual psalms of lament are important in our understanding of Psalm 37. This psalm is not intended to be a passport to unprecedented happiness and prosperity where sorrow and misfortune are unknown. The construct of retribution and reward - the connection between actions and consequences - which plays such a prominent part in the psalm must be interpreted in the light of the didactic purpose of the psalm as well. The aim of the psalm is to persuade the reader to act wisely, that is to live righteously and trust in the Lord. To achieve this aim, the poet depicts the righteous and the ungodly in sharp contrast to one another. This emerges clearly in the third strophe (vv 27-40), which sums up the two preceding strophes.

The conflict in Psalm 37 revolves around the question of the "land" (Brueggemann 1993:232). To whom does the land belong and to whom 
will it belong? The term land is to be understood in the sense of a blessing and a salvific gift, which Yahweh gave to Israel (Held 1993:298). The expression "the land" occurs five times in the psalm (vv 9, 11, 22, 29, 34; Brueggemann 1993:232; Zenger 1993:229). In Psalm 37 the ancient promise of land is directed to the righteous, the true Israel (Zenger 1993 236-238; Irsigler 1997:77). This promise is reinforced when the psalmist says that the wicked will be driven out of the land (vv 9, 22, 28, 34, 38). The supposition here is that the followers of Yahweh do not possess the land as a gift from Yahweh, or that their dwelling places are in danger (Irsigler 1997:77; Zenger 1993:236). The wicked are plotting the downfall of the righteous and threatening their lives ( $\mathrm{vv} 12$, 32). The wicked are rich and enjoy abundance (vv 16, 35).

But who are the righteous? Psalm 37 clearly emphasises the ethical and religious qualification of the righteous, and not their social status. They are those whose hope is in Yahweh(v 11), who are blessed by Him (v 22), his faithful ones (v 28), who had made the Torah of God their own and the source of wise and just utterances (vv 30-31). The righteous show solidarity with the weak and are generous and charitable towards them (vv 1, 26; Brueggemann 1993:236; Held 1993:300).

The third beatitude reads: "Blessed are those who do not use violence, for they will inherit the land” (Math 5:5). If we turn to verse 11 of Psalm 37 we read: "The poor will enter the land, they will delight in total prosperity". Though one may not immediately realise this, the words "poor" and "those who do not use violence" are identical. The Hebrew word anawîm and the LXX counterpart praies , "gentle", include the "powerless" (Lohfink 1997:234). The anawîm (v 11) which include the "powerless" are also those who bow down to Yahweh, the humble, who have been promised the fullness of the šalom (Zenger 1993: 235, 237; Irsigler 1997:78). The second distich in verse 14, which adds an explicit reference to the "poor and needy" could be a later editorial addition (Zenger 1993:230, 231, 236; Irsigler 1997:78). This expansion is undoubtedly a precise reflection of the contrast which the psalmist is emphasising between the righteous and the wicked. The righteous possess comparatively little ( $\mathrm{v}$ 16). This applies to both social impoverishment and the threat of famine. Nehemiah's concern with social justice in Judah (Neh 5: 1-13) may be an underlying assumption in Psalm 37 (Irsigler 1997:78). The downfall of the wicked (the rich) is foreseen in Psalm 37. The psalm is not, however, primarily a reflection on a social problem but 
rather a pronouncement on an existential and theological problem of the embattled followers of Yahweh (Irsigler 1997:79). The question is whether Yahweh will affirm the righteousness of the faithful and grant them justice. After all, Yahweh loves justice (mišpat) (v 28, cf v 33). The righteous are sorely tempted to commit wicked actions in their wholehearted opposition to and their envy of the rich and wicked people, in order to defend their own cause (Irsigler 1997:79).

The poet's sober judgment tells him that paradise is unlikely to be achieved on earth. He therefore looks to the future (vv 37-40). For the "man of peace" there is a future, where the wicked have none (Mays 1993:161). Life's hopes will be fulfilled in that future (including the hope of progeny). The land will belong to them. The prosperity of the righteous is defined in these terms. The only prospect for the faithless wicked is ruin (Brueggemann 1993:237-238, 247). Yahweh plays an active role in bringing the future of the righteous to pass ( $\mathrm{v} 4,17,23-24,33,34,39-40$ ) (Brueggemann 1993:249; Zenger 1993:238-239; Irsigler 1997:79).

Psalm 37 is not merely a wisdom doctrine for teaching in a wisdom school. The intention of the psalm operates at two levels. Firstly, the psalm tries to accommodate the inner tension, anger and anxiety of the readers ( $\mathrm{cf} \mathrm{vv} \mathrm{1,} \mathrm{7,} \mathrm{8).} \mathrm{The} \mathrm{expected} \mathrm{destruction} \mathrm{and} \mathrm{demise} \mathrm{of} \mathrm{the} \mathrm{wicked}$ (vv 12-13) removes from the righteous any desire to take violent action against the wicked (Zenger 1993:235; Irsigler 1997:80). The second intention of the psalm is the exhortation to people to trust in Yahweh, the faithful God, while going through anxious and painful times in their religious life The psalmist is also at pains to represent the faithful God who dispenses justice and aid to his faithful people who trust in Him (cf vv 17-19, 28, 33, 39-40) (Irsigler 1997:75). Those who trust in Yahweh will not be disappointed. Even if the turning point is not reached in the present, the just order will undoubtedly come to pass in the future (Irsigler 1997:80). The structure of Psalm 37 is a vehicle for this message.

The psalm begins with the trouble and uncertainty which the wicked bring into the lives of the followers of Yahweh (vv 1-2), and ends with the firm assurance that Yahweh will save the righteous (vv 39-40). The invitation to trust ( $\mathrm{vv} 3-5)$ grows into fulfilled trust by the end of the psalm, that is security with Yahweh (verses 39-40). Zenger (1993:238239) and Irsigler (1997:80) say that the righteous have already found refuge in Him. The certain hope of a fundamental change in social relations has led the followers of Yahweh to stand firm in their allegiance 
to Him and his just order in the present, despite contrary experiences (Irsigler 1997:81). As a "sermon text" Psalm 37 is a teaching instrument in the hands of a religious wisdom teacher. It gives him the opportunity to exercise pastoral persuasion to bring the righteous to trust in Yahweh (Mays 1994: 158-159; Irsigler 1997:76).

\section{THE HOMILETIC REVERBERATION OF PSALM 37 IN H J C PIETERSE'S HOMILETICS}

\subsection{The just man}

The central question in homiletics is: who is the just man (cf Ps 37:11, 22). What emerges from Pieterse's homiletic work is that man is justified. Because God has pardoned us through Christ, we can trust in God. For Pieterse (1988:1-8) the christological concentration is not negotiable. He has stuck to this consistently throughout his homiletic work. He does not see this as a pneumatological attennuation, however. On the contrary, the pneumatological actions find expression in christological deeds.

For Pieterse justice is not merely an imputed category but - and particularly - an ethical category (Pieterse 1995:2001). Someone who has been justified must act justly (cf Ps 37:27, 28, 30, 34, 37).

\subsection{The context}

A sermon cannot depend solely on a textual analysis. A text is rooted in a particular context (environment). This textual association also concerns the listener and his experiential world. The sermon writer therefore needs to pay attention to the text, the co(n)text and the listener. This emerges clearly from a reading of Psalm 37. Without a context, or outside its context, a sermon is nebulous and without meaning.

The power of Pieterse's homiletic writing lies in its actuality and his concentration on concrete reality. The here and now are the boundaries of the space within which the sermon must hit home. The reason is that "theology is essentially contextual" (Pieterse 1995:52). As Pieterse rightly points out (1995:108; 2001:28-70), the South African context is above all a context of poverty. The great majority of South Africans are poor and need to be liberated from this inhuman condition (Pieterse 1995:108). Poverty is not glorified. The pain associated with it is clinically and existentially described. The truth of reality and the reality of the truth - a painful truth - are clearly revealed.

The prophetic tradition clearly demonstrates that God is on the side 
of the victims of social injustice - who are usually the poor, the lonely and the outcasts (Pieterse 2001:83). This is the message of the Old Testament (Pss 37:11; 103:6; 146:6-9). It is also the message and the praxis of Jesus. He came for the poor, the hungry, the naked and the sick (Pieterse 1995:29). God's kingdom forms a stark contrast to the manmade kingdoms of power and riches. In this kingdom the values of reconciliation, peace, justice, love and forgiveness prevail. By proclaiming the kingdom in which God rules supreme Jesus was bringing good news to the poor (Lk 4:16-22; Pieterse 2001:84).

If God sides with the poor and the oppressed, the church and all Christians have to do the same. The church therefore identifies and has solidarity with the poor and the oppressed (Pieterse 1995:30; 2001:86). In Psalm 37 the solidarity of the righteous with the poor and the oppressed is revealed by their generosity and charity towards them (vv $21,26)$.

\subsection{Prophetic theology}

In this paragraph the focus is on the prophetic dimension of Psalm 37 and how at reverberates in the prophetic theology of H J C Pieterse. Prophetic theology reads the signs of the times with a view to criticism of the unjust, a call for action and hope for the victims of injustice (Pieterse 1995:28-29). Prophetic theology always sounds a call to action. The prophets call for repentance, conversion and change. They issue warnings about God's punishment and in the name of God they promise great blessings for those who do change (Pieterse 1995:29).

The prophetic approach prompts the church to get involved in society for the sake of fellow humans. Prophetic theology in South Africa is grounded in the Bible; it reads the signs of the times; it calls the church to action on behalf of the poor and the oppressed; it is confrontational to injustice and the evils of the political systems; it has a message of hope; it is deeply spiritual; it is practical and pastoral (Pieterse 1995:29). The practical and pastoral motif also emerges clearly in Psalm 37.

Prophetic theology is the source of prophetic preaching. Pieterse is aware that prophetic preaching is but one form of preaching, pertaining to social comment and socio-economic and political critique of a society and its body politic. Prophetic preaching has a few distinguishing characteristics (Pieterse 1995:68-70, 106-108, 110). The following are among the most notable which also occur in Psalm 37: 
1 Prophetic preaching should be existential, concrete and true to the historic reality of the context. This remark by Pieterse needs to be refined. One aspect which Pieterse does not touch on adequately is that prophetic preaching should give special attention to the socio-cultural context of the biblical text (cf 2.1). The biblical text is embedded in a particular historical and socio-cultural context (cf Klauck 1996; Neyrey 1998; Theissen 2000; Malina 2001).The message is communicated in relation to its context. The historical and socio-cultural reality is not immediately obvious. Access to these realities will always be a question for hermeneutics, reflection and subjectivity. We cannot look at the historical and socio-cultural context other than as at fragments.

2 Prophetic sermons should also contain good news for the poor and the oppressed (cf Ps 37). In this the good news of Jesus Christ's victory over the cross, his resurrection and ascension. To this we should add that the Holy Spirit allows people to experience this salvation in a comprehensive sense and to share it with each other.

3 Prophetic preaching should always inspire its listeners with a vision of liberation that will bring justice, peace and a better life for all. In prophetic preaching the injustices should be identified and pointed out. The preacher should be critical of everything that stands in the way of the development of the poor and the deprived and the reconstruction of the social order. Prophetic preaching in the context of poverty should not neglect the needs of the poor for justice and righteousness. Justice in relation to possessions, property and land should receive attention in prophetic preaching. This emerges in Psalm 37. Equal opportunity should be the basis for a society of peace and justice.

$4 \quad$ Prophetic sermons must be preached so that the listeners are able to respond to them obediently and transform the situation to a better one through action. Psalm 37 is the source of the following insight: dark and depressing circumstances cannot be altered by blind rage, violence and revenge. Faith in God and just actions are the only way to survive in circumstances of that kind.

\subsection{The future}

One of the gifts of Psalm 37 is a perspective on the future (vv 37-40). Preaching is always a gift of hope. Even though it may be hope against hope. Hope means continuing to hope in God, who is able to do the impossible. Righteousness creates hope. Pieterse's homiletics is not the 
homiletics of despair, but of hope - hope which can even triumph over poverty.

In Pieterse's description of liberation theology in South Africa he points out that the liberation theologians derived the theme of oppression from the Old and New Testaments (Pieterse 1995:32). It is a fundamental theme in the Bible, and God's answer to oppression is simple liberation (Pieterse 1995:32). Pieterse (1995:33) points out that it is a merit of liberation theology that the concept of liberation has been expanded in modern theology.

Salvation is not only meant for the forgiveness of the sins of individuals. Salvation also includes the social and political sphere of life (Pieterse 1995;33).

It has been this interpretation of the theme of liberation which has made it possible to sustain the hope of people in their crisis. In the context of oppression the biblical message of liberation was the good news of the gospel to which they could cling in faith (Pieterse 1995:33). The gift of hope in the preaching depends on the promise of God (Pieterse 1995:110). It is God's promise which gives people hope for the future and allows that hope to infuse their actions. It is only actions inspired by hope that offer a way out of a desperate situation. It is for this reason that the preacher must give his listeners concrete and attainable goals to strive for (Pieterse 1995:110). These would include pastoral goals such as a house-building project (Pieterse 1995:110). In his homiletics in a context of poverty Pieterse (2001:93-121) gives extensive and meaningful attention to preaching and pastoral development. Sermons are not part of the decor in the church; they must take on concrete form and new meaning in the lives of the listeners. This happens through community development, through support for community projects and through inspired participation in the process of transformation (Pieterse 2001:116-121).

A sermon is the interface between the present and the future. It is a new dawn which gives people in despair new hope and courage.

\section{CONCLUSION}

Hendrik J C Pieterse's outstanding writing has made him a pioneer in the field of Practical Theology, especially in South Africa, but also in the international arena. The seed which he has sown so faithfully and with such dedication will bear fruit a hundredfold in the years to come. 
Through his preaching he has rendered outstanding service to theology, the church and the Kingdom of God. Our hope is that after his $65^{\text {th }}$ birthday he will continue joyfully to gather in the homiletic harvest.

\section{Consulted literature}

Brueggemann, W 1993. Psalm 37: Conflict of Interpretation, in: McKay, H A \& Clines, D J A (eds), Of Prophets' Visions and the Wisdom of Sages: Essays in Honour of R. Norman Whybray on his Seventieth Birthday, (JSOT suppl series 162) 229-256. Sheffield: Sheffield Academic Press.

Held, H J 1993. Hoffen auf Gott und Entschlossenheit zum Guten: Unterweisung auf dem Weg der Gerechtigkeit in Psalm 37 und in der Bergpredigt, in: Mommer, P, Schmidt, H S, Schwab, E, Mitabeiter ( hrsg), Gottes Recht als Lebensraum: Festschrift für Hans Jochen Boecker, 293 - 302. Neukirchen-Vluyn: Neukirchener Verlag.

Irsigler, H 1997. Vom Adamssohn zum Immanuel. St Ottilien: E O S Verlag.

Klauck, H -J 1996. Die religiöse Umwelt des Urchristentums 11. Herrscher- und Kaiserkult, Philosophie. Stuttgart: Verlag W Kohlhammer.

Lohfink, N 1997. The appeasement of the Messiah: thoughts on Ps 37 and the third beatitude. T D 44 (3), 234 - 241.

Malina, B J 2001. The Social Gospel of Jesus. The Kingdom of God in Mediterranean Perspective. Minneapolis: Fortress Press.

Mays, J L 1994. Psalms, in: Mays, J L, Miller, P D Jr \& Achtemeier, P J (eds), Interpretation: A Bible Commentary for Teaching and Preaching. Louisville: John Knox Press.

Neyrey, J H 1998. Honor and Shame in the Gospel of Matthew. Louisville: John Knox Press.

Pieterse, H J C 1988. Die Woord in werklikheid. 'n Teologie van die Prediking. Pretoria: NG Kerkboekhandel.

-, (ed.) 1995. Desmond Tutu's Message. A Qualitative Analysis. Kampen: Kok Pharos/Weinheim: Deutcher Studien Verlag.

-, 2001. Preaching in a context of Poverty. Pretoria: University of Pretoria.

Sitzler, D 1995. Vorwurf gegen Gott. Ein religiöses Motiv im Alten Orient (Ägypten und Mesopotamien) (StOR 32): Wiesbaden: Harrassowitz

Theissen, G 2000. Die Religion der ersten Christen. Eine Theorie des Urchristentums. Chr. Kaiser: Gütersloher Verlagshaus.

Van der Ploeg, J P M 1973. Psalmen, Deel 1 (BOT). Roermond: J J Romen \& Zonen. Van Uchelen, N A 1971. Psalmen deel 1. (POT) Nijkerk: Callenbach.

Weiser, A 1987. Die Psalmen, Erster Teil: Psalm 1-60 (ATD). 10. unveränderte Auflage. Zürich: Vandenhoeck und Ruprecht.

Zenger, E 1993. Die Nacht wird leuchten wie der Tag. Psalmauslegungen. Freiburg: Herder. 